\title{
STUDI ENVIRONMENTAL KUZNETS CURVE DI ASIA: SEBELUM DAN SETELAH MILLENNIUM DEVELOPMENT GOALS
}

\author{
STUDY OF ENVIRONMENTAL KUZNETS CURVE IN ASIA: BEFORE \\ AND AFTER MILLENNIUM DEVELOPMENT GOALS
}

\author{
Sri Indah Nikensari ${ }^{1 *}$, Sekar Destilawati ${ }^{1 * *}$, Siti Nurjanah ${ }^{1 * * *}$ \\ ${ }^{1}$ Departemen Ekonomi, Universitas Negeri Jakarta, Jakarta, Indonesia \\ *indah_nikensari@unj.ac.id,**pe8105152586@gmail.com,***siti.nurjanah@unj.ac.id
}

\begin{abstract}
Abstrak
Pencemaran lingkungan dapat menurunkan kesejahteraan subyektif(subjective well-being). Studi ini bertujuan membuktikan berlakunya hipotesis Environmental Kuznets Curve (EKC) di negara-negara berpendapatan tinggi dan menengah Asia, juga untuk menganalisis perbedaan pengaruh GDP per kapita, konsumsi energi, dan populasi penduduk pada emisi $\mathrm{CO}_{2}$ di wilayah yang sama pada periode sebelum dan setelah MDGs. Data diperoleh dari World Bank dengan periode waktu 1987-2014, di mana analisisnya menggunakan metode kuantitatif dan expose facto, dan melalui persamaan regresi data panel guna mencapai tujuan penelitian. Hasil penelitian membuktikan bahwa sampai 2014 hipotesis EKC yang berbentuk U-terbalik belum terjadi di negara-negara high income yang diteliti, namun akan terjadi ketika GDP per kapita sudah mencapai USD 51.44 ribu. Sedangkan di negara-negara lower middle income, pola hubungan antara GDP per kapita dan emisi $\mathrm{CO}_{2}$ masih membentuk kurva U, atau dengan kata lain hipotesis EKC belum akan terjadi di negara-negara ini, karena di beberapa negara tersebut masih dalam tahap awal pembangunan. Hasil penelitian juga menunjukkan bahwa sebelum MDGs (tahun 2000), GDP per kapita, konsumsi energi dan jumlah penduduk di negara-negara high income berkontribusi atas naiknya emisi $\mathrm{CO}_{2}$, namun pasca MDGs ditetapkan, meningkatnya GDP per kapita mampu menurunkan emisi $\mathrm{CO}_{2}$. Sedangkan di negara-negara low middle income, di awal penelitian sebelum MDGs, data menunjukkan bahwa CO2 sudah tinggi pada saat GDP per kapita masih rendah, dan pasca MDGs, kenaikan GDP per kapita masih berkontribusi atas meningkatnya emisi CO2.
\end{abstract}

Kata kunci: subjective well-being, environmental economics, Kuznets Curve, GDP per capita

Klasifikasi JEL: I31, Q51, Q53, Q56

\begin{abstract}
The environmental pollution can reduce subjective well-being.Thus study aims to prove the validity of the Environmental Kuznets Curve (EKC) hypothesis in high and middle income countries in Asia, also to analyze the differences in the effect of GDP per capita, energy consumption, and population on CO2 emissions in the same region before and after the MDGs. Data obtained from the World Bank for the period 1987-2014, where the analysis uses quantitative methods and expose facto, and through panel data regression equations to achieve research objectives. The results show that until 2014 the EKC hypothesis in the form of U-reversal has not occurred in the high income countries studied, but will occur when GDP per capita has reached USD 51.44 thousand. Whereas in the lower middle income countries, the pattern of the relationship between GDP per capita and CO2 emissions still forms a U curve, or in other words the ECC hypothesis will not occur in these countries, because in some countries it is still in the early stages of development. The results also showed that prior to the MDGs (2000), GDP per capita, energy consumption and population in high income countries contributed to the increase in CO2 emissions, but after the MDGs, rising GDP per capita was able to reduce CO2 emissions. Whereas in low middle income countries, at the beginning of the study before the MDGs, the data showed that CO2 was already high at a time when GDP per capita was still low, and after MDGs, increases in GDP per capita still contributed to rising CO2 emissions.
\end{abstract}

Keywords: Subjective well-being, environmental economics, Kuznets Curve, GDP per capita

JEL Classification: I31, Q51, Q53, Q56 


\section{PENDAHULUAN}

Dalam beberapa dekade terakhir, percepatan industrialisasi, konsumsi energi, populasi penduduk, dan perubahan perilaku hidup telah memicu permasalahan lingkungan (Maryam, Mittal, \& Sharma, 2017). Penurunan kualitas lingkungan telah diakui secara global, dan menjadi bagian dari isu perubahan iklim dunia. Organisasi internasional World Economic Forum $(W E F)$ menyatakan bahwa perubahan iklim adalah masalah terserius yang mempengaruhi dunia (WEF, 2017). Selama tahun 1880 sampai 2015 perubahan suhu permukaan bumi mengalami tren yang meningkat yaitu sebesar $0,07^{\circ} \mathrm{C}$ per dekade (Pratama, 2016). Masalah perubahan iklim, diakui dunia sebagai ekternalitas negatif akibat kegiatan ekonomi tiap negara, yang dilakukan secara tidak berkelanjutan.

Pembangunan menjadi tidak berkelanjutan bila fokusnya hanya untuk mencapai pertumbuhan ekonomi yang tinggi. Dalam proses mendorong laju pertumbuhan yang tinggi, pengabaian aspek lingkungan menyebabkan menurunnya kualitas lingkungan (Phimphanthavong, 2013). Kualitas lingkungan yang rendah, khususnya polusi udara, menyebabkan menurunnya kesehatan (Landrigan 2017), menurunnya kebahagian (Goetzke and Rave 2015), dan menurunnya kesehatan dan kesejahteraan subyektif (Zhang, Zhang, and Chen 2017). Kesejahteraan subyektif (subjective well-being) yang antara lain berkaitan dengan kebahagiaan, kepuasan hidup dan pengaruh positif, merupakan salah satu dari tiga dimensi pembangunan berkelanjutan, yaitu lingkungan, sosial, dan ekonomi.

Urgensi pencapaian pertumbuhan ekonomi, dan kelestarian lingkungan adalah dua hal yang sama pentingnya. Hal ini sejalan dengan disepakatinya program MDGs (Millennium Development Goals) oleh 189 negara anggota Perserikatan Bangsa Bangsa (PBB) pada Konferensi Tingkat Tinggi di New York pada 6-8 September tahun 2000, dan berakhir tahun 2015, yang kemudian dilanjutkan dengan Sustainable Development Goals (SDG) mulai 2016. MDGs sendiri memiliki delapan target, target ke tujuh dari delapan arah pembangunan yang disepakati adalah menjamin keberlangsungan lingkungan. Tujuan tersebut memiliki target utama diantaranya adalah memadukan prinsip-prinsip pembangunan berkelanjutan dengan kebijakan dan program nasional serta mengembalikan sumber daya lingkungan yang hilang (Susanti, 2018). Indikator yang digunakan untuk mengukur keberhasilan target ini salah satunya adalah jumlah emisi $\mathrm{CO}_{2}$. Hal ini berarti bahwa pemerintah harus menerapkan pembangunan berkelanjutan untuk menjamin kelestarian lingkungan di masa sekarang dan yang akan datang, terutama mengendalikan jumlah emisi $\mathrm{CO}_{2}(\mathrm{OECD}, 2015)$.

World Meteorological Organization (WMO) menyatakan bahwa $\mathrm{CO}_{2}$ ialah penyebab utama pemanasan global yang terjadi (WMO, 2017). Emisi $\mathrm{CO}_{2}$ melonjak tajam dalam abad terakhir karena aktivitas manusia, terutama oleh penggunaan konsumsi bahan bakar fosil seperti batubata, minyak dan gas, kegiatan manufaktur, transportasi, serta konsumsi barang dan jasa yang secara langsung terkait dengan pertumbuhan ekonomi. Sehingga terdapat hubungan sistematis antara pertumbuhan ekonomi dan kualitas lingkungan, yang dikenal sebagai Environment Kuznet Curve (EKC) yang membentuk kurva U-terbalik. Hipotesis EKC hadir sebagai pengembangan Grossman dan Krueger (1995) atas teori Kuznets pada tahun 1991 mengenai kurva U-terbalik yang menjelaskan hubungan antara ketimpangan pendapatan dengan pertumbuhan ekonomi, dimana pada awal pertumbuhan ekonomi ketimpangan meningkat, namun ketimpangan akan menurun seiring dengan meningkatnya pertumbuhan ekonomi.

Setelah ditemukan, hipotesis EKC kemudian dipopulerkan dalam World Development Report 1992 oleh Bank Dunia yang memandang bahwa kegiatan ekonomi yang lebih besar tidak terelakkan lagi akan merusak lingkungan. Setelah itu, hipotesis EKC menjadi bahan riset yang menarik, seiring dengan menguatnya isu penurunan kualitas lingkungan global.

Berbagai riset telah dilakukan, akan tetapi, hipotesis EKC sebagai bentuk analisis empiris masih dipertanyakan konsistensinya. Hal ini terkait dengan variasi temuan penelitian pada model EKC. Beberapa penelitian di berbagai kawasan ada yang dapat membuktikan berlakunya hipotesis EKC dengan bentuk kurva U-terbalik dalam jangka panjang, salah satunya adalah 
yang terjadi di Paskitan (Ali, Khatoon, Ather, \& Akhtar, 2015), di Ethiopia (Endeg, 2015), dan di negara-negara di dunia berpendapatan tinggi (Camci-Cetin, Kutluturk, and Cetin 2018). Namun, beberapa penelitian terkait EKC justru kontradiktif dengan hipotesis EKC. Penelitian oleh Basarir \& Arman (2013) mengungkapkan bahwa EKC tidak secara penuh terbukti di negara Gulf Cooperation Council. Selain itu, kebenaran EKC juga tidak ditemukan di Afrika Selatan (Inglesi-Lotz \& Bohlmann, 2014), di negara-negara dunia berpenghasilan menengah dan rendah (Camci-Cetin, Kutluturk, and Cetin 2018). EKC bahkan berbentuk $N$ di negara OECD, dan non-OECD, yaitu di Amerika Latin, Asia, dan Afrika (Beck \& Joshi, 2015).

Masih adanya perbedaan dan perdebatan mengenai hipotesis EKC tersebut, penelitian ini bertujuan untuk membuktikan pola U-terbalik hipotesis EKC pada dua kelompok negara di Asia, yaitu negara-negara berpendapatan tinggi (high income countries/HIC) dan negara-negara berpendapatan menengah rendah (lower middle income countries/LMIC). Dengan mengetahui pola hubungan antara pertumbuhan ekonomi dan emisi $\mathrm{CO} 2$, pemerintah di masing-masing negara diharapkan dapat mengambil tindakan atau melakukan kebijakan pembangunan yang ramah lingkungan. Selanjutnya, penelitian juga untuk memeriksa perbedaan pengaruh yang diberikan oleh pertumbuhan ekonomi, konsumsi energi, dan populasi penduduk terhadap emisi $\mathrm{CO} 2$ antara sebelum dan setelah berlakunya program MDGs pada tahun 2000. Penulisan artikel ini mengikuti urutan penulisan sebagai berikut: bagian 1 tentang pendahuluan, bagian 2 berisi kajian pustaka, bagian 3 berbicara tentang metode penelitian, bagian 4 menyajikan hasil penelitian dan pembahasan, bagian 5 berisi kesimpulan dan rekomendasi.

\section{TINJAUAN PUSTAKA}

Tujuan pembangunan berkelanjutan (Sustainable Development Goals/ SDGs) dengan 17 tujuan pembangunan berkelanjutan yang dicanangkan oleh United Nations sejak akhir 2015 hingga 2030, merupakan kelanjutan atas tujuan MDGs. Agenda pembangunan berkelanjutan ini dibuat untuk menjawab tuntutan kepemimpinan dunia dalam mengatasi kemiskinan, kesenjangan, dan perubahan iklim dalam bentuk aksi nyata, dan akan diaplikasikan secara universal serta dapat diukur dalam menyeimbangkan tiga dimensi pembangunan berkelanjutan yakni lingkungan, sosial, dan ekonomi.

Adapun Millennium Development Goals (MDGs) sendiri yang merupakan program awal, telah menempatkan pembangunan manusia sebagai fokus utama pembangunan serta memiliki tenggat waktu dan kemajuan yang terukur. Arah pembangunan yang disepakati secara global meliputi: (1) menghapuskan kemiskinan dan kelaparan, (2) mewujudkan pendidikan dasar untuk semua orang, (3) mempromosikan kesetaraan gender dan pemberdayaan perempuan, (4) menurunkan kematian anak, (5) meningkatkan kesehatan, (6) melawan penyebaran HIV/ AIDS dan penyakit kronis lainnya, (7) menjamin keberlangsungan lingkungan, dan (8) mengembangkan kemitraan global untuk pembangunan (United Nation, 2007). Salah satu tujuan MDGs adalah memasikan kelestarian lingkungan hidup. Tujuan ini memiliki tiga target utama yaitu memadukan prinsip-prinsip pembangunan berkelanjutan dengan kebijakan dan program nasional serta mengembalikan sumber daya lingkungan yang hilang.

Salah satu wujud penurunan kualitas lingkungan adalah adanya pemanasan global. World Meteorological Organization (WMO) menyatakan bahwa $\mathrm{CO}_{2}$ ialah penyebab utama pemanasan global yang terjadi (WMO, 2017). Banyak faktor yang mempengaruhi emisi karbon dioksida $\left(\mathrm{CO}_{2}\right)$. Salah satu ahli yaitu, Suparmoko menyebutkan bahwa dengan berkembangnya waktu, dan semakin meningkatnya pembangunan akan berdampak pada penurunan fungsi lingkungan sebagai akibat dari meningkatnya pencemaran (Suparmoko, 2000). Pendapat Suparmoko di dukung oleh Kementerian Negara Lingkungan Hidup yang menyatakan aktivitas manusia di dalam melaksanakan pembangunan telah menimbulkan perubahan terhadap lingkungan yang merugikan manusia, misalnya kerusakan dan pencemaran lingkungan (Kementerian Negara Lingkungan Hidup, 2009).

Naiknya konsentrasi $\mathrm{CO}_{2}$ dipengaruhi oleh jumlah populasi, pertumbuhan ekonomi, 
perkembangan teknologi, dan faktor lainnya (UNFCC, 2007). Pertumbuhan ekonomi telah banyak menebang pohon, merusak lahan, membanjiri sungai, dan jalur air serta atmosfir dengan banyak polutan. Emisi karbondioksida 60 persen berasal dari sektor ekonomi yang memerlukan energi seperti industri, transportasi, permukiman, dan komersial. Sedangkan 25 persen berasal dari sektor kehutanan, dan 15 persen dari sektor pertanian (World Resource Institute, 2016).

Konsumsi energi ialah salah satu faktor yang mampu mempengaruhi emsi $\mathrm{CO}_{2}$. Lean \& Smyth (2010) menjelaskan bahwa satu persen kenaikan pada konsumsi energi listrik perkapita, dapat mempengaruhi peningkatan emisi $\mathrm{CO}_{2}$ per kapita. Selanjutnya Zhu dan Peng, mendapatkan hasil penelitian bahwa perubahan tingkat konsumsi energi dan populasi penduduk merupakan faktor pengaruh utama terhadap jumlah intensitas emisi karbon (Zhu \& Peng, 2012). Dengan studi kasus tempat yang berbeda, melalui penelitiannya juga membuktikan bahwa pertumbuhan ekonomi, dan konsumsi energi mempengaruhi emisi karbondioksida (Pao \& Tsai, 2011).

Pertumbuhan ekonomi dan emisi $\mathrm{CO}_{2}$ dijelaskan dalam sebuah hipotesis bernama Environmental Kuznets Curve (EKC). Hipotesis EKC memperlihatkan kontribusi pertumbuhan ekonomi terhadap emisi yang lebih tinggi tetapi pertumbuhan ekonomi lebih lanjut kemudian mampu menurunkan degradasi lingkungan. Hal ini dikarenakan kemajuan teknologi dan pergeseran ke ekonomi berbasis jasa (Galeotti, 2007).

Hipotesis EKC menjelaskan bahwa pertumbuhan ekonomi awalnya akan meningkatkan degradasi lingkungan. Hal ini dikarenakan negara akan berfokus pada peingkatan produksi tanpa memperhatikan aspek lingkungan. Proses produksi yang dilakukan secara terusmenerus kemudian akan mengakibatkan degradasi lingkungan berupa pencemaran baik terhadap tanah, air, maupun udara. Pertumbuhan ekonomi pada titik tertentu kemudian akan menyadarkan masyarakat bahwa kebutuhan akan kualitas lingkungan yang baik menjadi sanga penting. Titik inilah yang disebut sebagai titik balik (turning point) dimana pertumbuhan ekonomi akan menurunan degradasi lingkungan (Shaharir \& Alinor, 2013).

Berdasarkan Gambar 1 yang menjelaskan tahapan yang terjadi dalam hubungan pertumbuhan ekonomi dan kualitas lingkungan, terlihat bahwa tahapan EKC terbagi menjadi tiga. Penjelasan pertama dari hubungan kurva U-terbalik Kuznet adalah tahapan pertumbuhan ekonomi melalui transisi dari pertanian ke industri, kemudian pasca-industri dengan system perekonomian berbasis jasa. Kerusakan lingkungan cenderung naik karena perubahan struktur ekonomi dari pedesaan ke perkotaan, dan dari pertanian ke industri sebagai produksi masal, dan pertumbuhan konsumsi. Hal ini kemudian menurun dengan perubahan struktur ekonomi yang kedua dari industri berat berbasis energi menjadi industri dan jasa berbasis teknologi (Panayotou, 1993). Pada tahap pertama dari industrialisasi, polusi bertambah dengan cepat karena orang lebih tertarik dalam pekerjaan dan pendapatan daripada udara dan air bersih. Berkaitan dengan itu, masyarakat terlalu miskin untuk membayar pengendalian dan regulasi lingkungan pun tidak bertanggungjawab (Dasgupta, Laplante, Wang, \& Wheeler, 2002).

Pada tingkat pendapatan yang rendah, negara akan beralih dari pertanian ke industri dan intensitas polusi naik sebagai limbah dari bertumbuhnya produksi dan konsumsi masal. Hal ini dikarenakan penggunaan sumber daya alam yang lebih besar, emisi polusi yang lebih banyak, dan tuntutan kenaikan output. Sedangkan pada tingkat pendapatan yang tinggi, kemajuan pembangunan ekonomi didominasi pada pascaindustri atau perekonoman jasa. Pada tahap ini kesadaran linkungan naik, pengeluaran untuk lingkungan lebih tinggi, efisiensi teknologi, dan kenaikan permintaan barang/jasa ramah lingkungan (Mrabet, Achairi, \& Ellouze, 2014). Pergerakan kurva yang mulai seimbang membawa sektor industri menjadi lebih bersih, orang menghargai lingkungan lebih tinggi, dan regulasi menjadi lebih efektif (Dasgupta et al., 2002).

Bukti empiris memercayai pada bentuk regresi dari kualitas lingkungan hubungannya dengan pendapatan dan variabel lainnya. Hubungan empiris ini berpendapat bahwa pertumbuhan ekonomi dengan sendirinya merupakan obat 


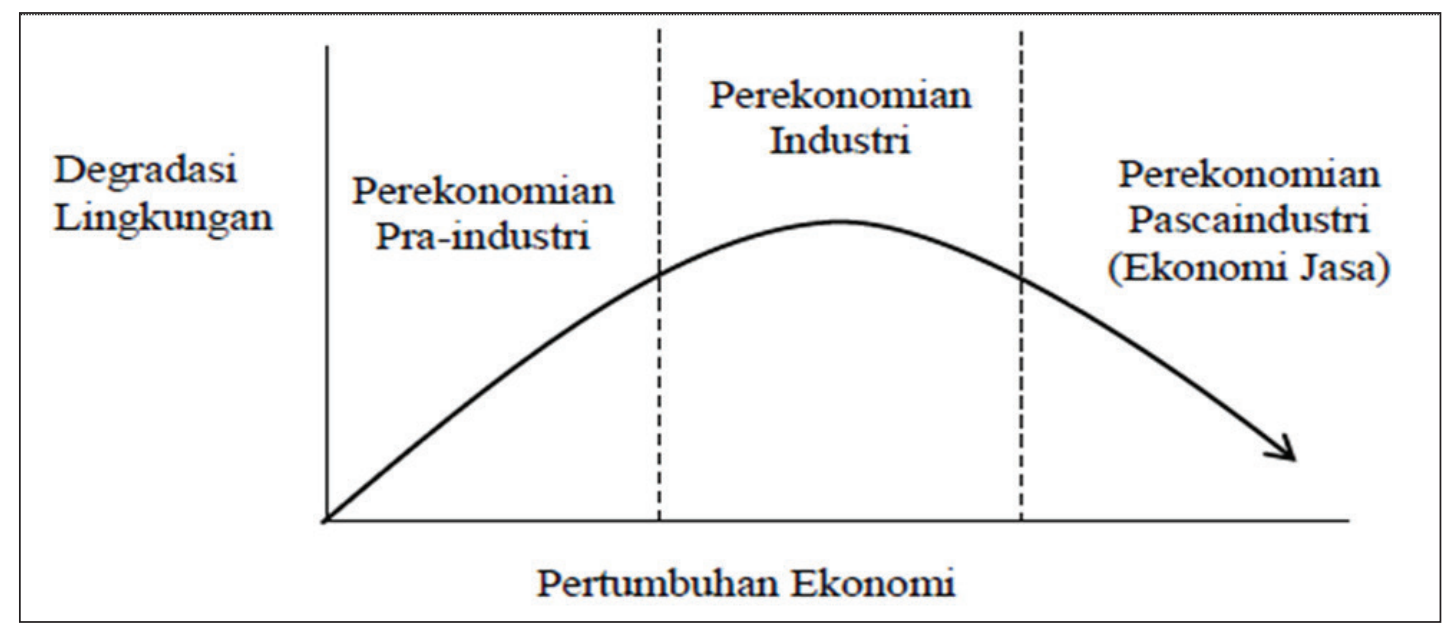

Sumber: Shaharir \& Alinor, 2013

Gambar 1. Proses Titik Balik Hipotesis EKC

mujarab bagi degradasi lingkungan. Beckerman menuliskan bahwa "in the end the best - and probably the only - way to attain a decent environment in most countries is to become rich". Artinya, akhir jalan terbaik untuk mencapai lingkungan yang layak bagi banyak negara adalah menjadi kaya (Beckerman, 1992). Hal ini berarti bahwa menjadikan lingkungan yang layak atau kualitas lingkungan yang bagus slah satu caranya dengan menjadikan sebuah negara yang kaya. Negara yang kaya dicerminkan dari GDP yang tinggi akan memiliki kemampuan membayar kerusakan lingkungan yang lebih tinggi pula, sehingga kualitas lingkungan akan terjamin.

\section{METODE PENELITIAN}

Peneliti menggunakan data panel tahun 19872014 pada 10 negara kelompok high income dan 10 negara kelompok low middle income di Asia. Negara-negara dalam kategori high income meliputi Singapura, Jepang, Korea Selatan, Hongkong, Brunei Darussalam, Bahrain, Israel, Saudi Arabia, United Emirates Arab, dan Oman. Sedangkan negara-negara dalam kategori lower middle income meliputi Vietnam, Philipina, Myanmar, Indonesia, India, Sri Lanka, Banglades,Tunisia, Mongolia, dan Morocco.

Variabel yang digunakan dalam penelitian terdiri dari 5 variabel, yaitu emisi $\mathrm{CO}_{2}$ sebagai variabel terikat, pertumbuhan ekonomi, populasi penduduk, dan konsumsi energi sebagai variabel bebas. Data PDB per kapita, konsumsi energi, dan populasi penduduk diperoleh dari World Bank Development Indicators. Emisi $\mathrm{CO}_{2}$ diukur dalam satuan metrik ton per kapita dalam ribuan, pertumbuhan ekonomi diukur dengan PDB per kapita konstan 2010 US\$ dalam ribuan, populasi penduduk diukur dengan satuan juta penduduk total per tahun, dan konsumsi energi diukur sebagai energy use in $\mathrm{kg}$ of oil equivalent per capita dalam ribuan. Penelitian ini juga menggunakan dummy tahun 2000 untuk mengetahui perbedaan pengaruh variabel bebas terhadap variabel terikat sebelum dan setelah disepakatinya MDGs.

Untuk menjawab tujuan penelitian, digunakan metode kuantitatif dan metode expose facto. Metode kuantitatif dipakai untuk menjelaskan penyajian data berupa table dan grafik, sedangkan metode expose facto digunakan untuk menguji hipotesis EKC, serta melihat perubahan pengaruh pertumbuhan ekonomi, populasi, dan konsumsi energi antara sebelum dan setelah berlakunya MDGs di Asia.

Penelitian menggunakan model persamaan kuadratik, untuk dapat mengetahui pola U-terbalik yang terbentuk dari hubungan pertumbuhan ekonomi dan emisi $\mathrm{CO}_{2}$. Untuk itu peneliti menambahkan variabel pertumbuhan ekonomi kuadrat. Berikut ini adalah persamaan yang digunakan peneliti untuk menjawab permasalahan dalam penelitian ini. 
$\mathrm{CO} 2_{\text {it }}=\alpha+\beta_{1} \mathrm{PDB}_{\text {it }}+\beta_{2} \mathrm{PDB}^{2}{ }_{\text {it }}+\beta_{3} \mathrm{POP}_{\text {it }}$

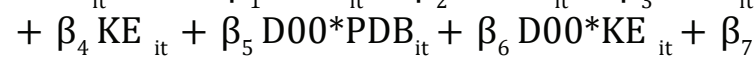
$\mathrm{D} 00 * \mathrm{POP}_{\mathrm{it}}+\varepsilon_{\mathrm{it}}$

Keterangan:

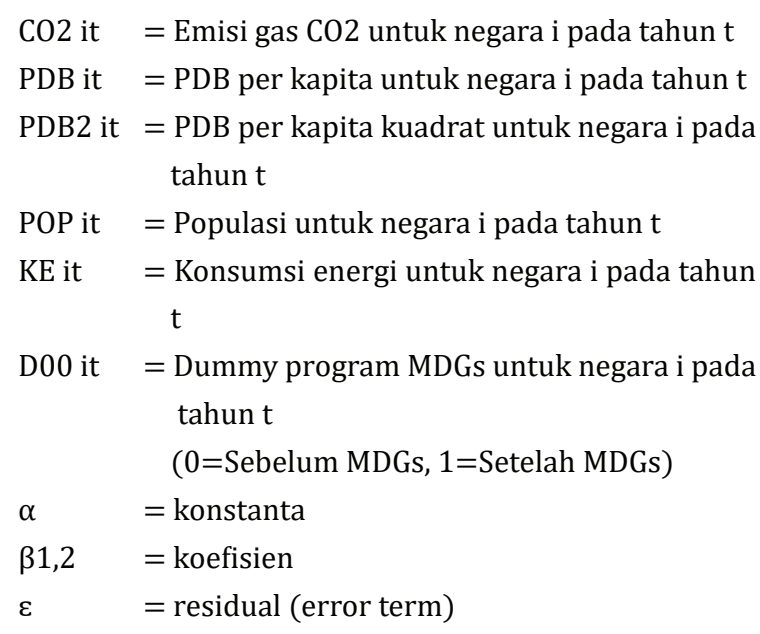

Berdasarkan persamaan diatas, untuk mengestimasi berlakunya hipotesis EKC di negara-negara high income dan negara-negara lower middle income di Asia, didasarkan pada syarat-syarat berikut:

a. Jika $\beta_{2}<0$, terjadi hubungan berbentuk Uterbalik

b. Jika $\beta_{2} \geq 0$, terjadi hubungan berbentuk $\mathrm{U}$

c. Turning point $=\frac{-\beta 1-\beta 1}{2 \beta 22 \beta 2}$

Berdasarkan syarat-syarat diatas, dapat diartikan bahwa hipotesis EKC terjadi apabila secara signifikan variabel PDB per kapita bernilai positif dan kuadrat PDB per kapita bernilai negatif. Selanjutnya, untuk mengetahui perubahan pengaruh pertumbuhan ekonomi, populasi penduduk, dan konsumsi energi terhadap emisi $\mathrm{CO}_{2}$ antara sebelum dan setelah berlakunya program MDGs, dapat dilihat dari nilai dummy tiap variabel bebas. Apabila dummy signifikan berarti terdapat perubahan yang terjadi pada variabel tersebut setelah berlakunya MDGs.

Sebelum melakukan estimasi, persamaan data panel harus melalui beberapa tahapan analisis data. Pertama adalah menentukan model terbaik, antara Common Effects Model (CEM), Fixed Effect Model (FEM), dan Random Effect Model (REM). Untuk mengetahui model terbaik, maka dilakukan Chow Test, Hausman Test, dan
Lagrange Multiplier. Setelah mendapatkan model terbaik, langkah selanjutnya adalah melakukan beberapa uji, yakni uji normalitas dan uji asumsi klasik (untuk persamaan regresi model OLS).

Uji normalitas residual dalam penelitian ini menggunakan uji Jarque -Bera (JB). Jika hasil dari JB statistik $>$ Chi Square tabel, maka data tidak berdistribusi secara normal. Sedangkan jika hasil dari JB statistik $<$ Chi Square tabel, maka data berdistribusi secara normal (Gujarai, 2010). Masih menurut Gujarati, multikolinearitas dapat dilihat dari nilai koedisien korelasi antar sesama variabel bebas. Jika nilai probabilitasnya lebih kecil dari 0,8 maka tidak ada masalah multikolinearitas, namun jika probabilitasnya lebih besar dari 0,8 maka ada masalah multikolinearitas. Terakhir, heteroskedastisitas dapat diuji dengan uji Glejser. Uji Glejser dilakukan dengan cara meregresikan variabel-variabel bebas terhadap residual absolut. Heteroskedastisitas terjadi apabila nilai residual dari model tidak memiliki varians yang konstan. Heterokedastisitas biasanya terjadi pada data cross-section sehingga tidak menutup kemungkinan terjadi heteroskedastisitas pada data panel. Berkaitan dengan hal tersebut, permasalahan heteroskedastisitas dapat diatasi dengan penggunaan estimasi Generalized Least Square (GLS), metode ini mampu mempertahankan sifat efisiensi estimatornya, tanpa harus menghilangkan sifat ketidakbiasan (unbiased) dan konsistensi estimator.

\section{HASIL DAN PEMBAHASAN}

Pemilihan model terbaik menggunakan uji likelihood ratio dan uji Hausman, di negara-negara high income dan negara lower middle income dengan menggunakan aplikasi E-Views 9. Hasil pengujian menunjukkan bahwa model terbaik dalam penelitian ini adalah fixed effect model (FEM). FEM dipilih sebagai model estimasi terbaik karena mendukung tujuan peneliti, dan juga memiliki $A d j-R^{2}$ tertinggi dan signifikan dengan taraf nyata $5 \%$ untuk seluruh bariabel bebas yang digunakan dalam model penelitian ini. Selain itu, penelitian ini juga melakukan pembobotan cross section weight (GLS dengan menggunakan estimasi varians residual cross 
section, karena terdeteksi adanya masalah heteroskedastisitas), dan pembobotan SUR (GLS dengan menggunaan covariance matrix cross section). Setelah mendapat persamaan model terbaik, selanjutnya dilakukan uji normalitas dan uji asumsi klasik. Hasil uji normalitas data residual menunjukkan bahwa data residual dalam penelitian ini masih normal, dan dari uji multikolinearitas dan uji heteroskedastisitas menunjukkan tidak adanya penyimpangan gejala klasik dalam penelitian ini. Berikut ini adalah persamaan regresi data panel dengan model Fixed Effect Model:

Negara-negara berpendapatan tinggi:

$\mathrm{CO}_{2}=-1.09 * \mathrm{D} 00 * \mathrm{GDP}+2.24 * \mathrm{D} 00 * \mathrm{KE}+$ $0.549 * \mathrm{D} 00 * \mathrm{POP}+3.49 * \mathrm{GDP}-0.03 * \mathrm{GDP} 2+$ $5.00 * \mathrm{KE}+24.43 * \mathrm{POP}-405.66$

Negara-negara berpendapatan rendah:

$\mathrm{CO}_{2}=17.79 * \mathrm{D} 00 * \mathrm{GDP}+20.70 * \mathrm{D} 00 * \mathrm{KE}-$ $0.08 * \mathrm{D} 00 * \mathrm{POP}-68.74 * \mathrm{GDP}+6.59 * \mathrm{GDP} 2+$ 118.6*KE + 3.53*POP - 460.27
Keterangan:

$\mathrm{CO}_{2}$ : Emisi $\mathrm{CO}_{2}$

GDP : Pendapatan per kapita

GDP $^{2}$ : Pendapatan per kapita kuadrat

KE : Konsumsi Energi

POP : Populasi Penduduk

D00 : Dummy Variabel (Nilai 0, untuk periode sebelum MDGs; Nilai 1, untuk setelah MDGs)

Atas dua persamaan diatas kemudian dilakukan uji hipotesis dan analisis koefisien determinasi $\left(\mathrm{R}^{2}\right)$. Uji hipotesis diperlukan untuk mengetahui apakah koefisien regresi yang diperoleh menunjukkan hasil signifikan atau tidak. Sedangkan Pengujian koefisien determinasi dilakukan untuk melihat seberapa besar variabel bebas yang digunakan peneliti mampu menjelaskan emisi $\mathrm{CO}_{2}$ sebagai variabel terikatnya. Hasil uji hipotesis dan analisis koefisien determinasi, dirangkum dalam tabel 1 berikut ini.

Tabel. 1 Ringkasan Hasil Uji Hipotesis dan Analisis Kefisien Determinasi

\begin{tabular}{|c|c|c|c|c|c|c|}
\hline Sampel & $\begin{array}{l}\text { Variabel } \\
\text { Dependen }\end{array}$ & $\begin{array}{c}\text { Variabel } \\
\text { Independen }\end{array}$ & Koef & $\begin{array}{c}\text { Prob. } \\
\text { T-statistik }\end{array}$ & $\begin{array}{c}\text { Prob. } \\
\text { F-statistik }\end{array}$ & $\operatorname{Adj}-R^{2}$ \\
\hline \multirow{7}{*}{$\begin{array}{l}\text { High Income } \\
\text { Countries }\end{array}$} & \multirow{7}{*}{$\mathrm{CO}_{2}$} & $\mathrm{D} 00 * \mathrm{GDP}$ & -1.233 & 0.000 & \multirow{7}{*}{0.000} & \multirow{7}{*}{0.994} \\
\hline & & $\mathrm{D} 00 * \mathrm{KE}$ & 2.566 & 0.000 & & \\
\hline & & D00*POP & 0.552 & 0.000 & & \\
\hline & & GDP & 4.553 & 0.000 & & \\
\hline & & $\mathrm{GDP}^{2}$ & -0.049 & 0.000 & & \\
\hline & & $\mathrm{KE}$ & 5.708 & 0.000 & & \\
\hline & & POP & 24.39 & 0.000 & & \\
\hline \multirow{7}{*}{$\begin{array}{l}\text { Lower } \\
\text { Middle } \\
\text { Income } \\
\text { Countries }\end{array}$} & \multirow{7}{*}{$\mathrm{CO}^{2}$} & $\mathrm{D} 00 * \mathrm{GDP}$ & 19.239 & 0.000 & \multirow{7}{*}{0.000} & \multirow{7}{*}{0.985} \\
\hline & & $\mathrm{D} 00 * \mathrm{KE}$ & -24.994 & 0.000 & & \\
\hline & & D00*POP & 0.4590 & 0.014 & & \\
\hline & & GDP & 48.773 & 0.000 & & \\
\hline & & $\mathrm{GDP}^{2}$ & -7.247 & 0.000 & & \\
\hline & & $\mathrm{KE}$ & 46.965 & 0.000 & & \\
\hline & & POP & 0.861 & 0.000 & & \\
\hline
\end{tabular}

Sumber: Data diolah 
Tabel 1 menunjukkan bahwa secara parsial (uji t) diketahui bahwa setiap variabel bebas memberikan pengaruh yang signifikan terhadap variabel terikatnya. Siginifikansi tiap variabel bebas terhadap variabel terikat dapat terlihat dari nilai probabilitas t-statistik kurang dari 0.05 . Sedangkan bila dilihat secara simultan (uji F), diketahui bahwa seluruh variabel bebas dalam setiap model tersebut secara bersama-sama memiliki pengaruh signifikan terhadap emisi $\mathrm{CO}_{2}$. Kesimpulan tersebut didapat dari nilai Prob. $\mathrm{F}$ statistik yang nilainya kurang dari 0.05 .

Berdasarkan tabel 1 diatas, diketahui pula hasil pengujian koefisien determinasi $\left(\mathrm{R}^{2}\right)$ baik di high income countries maupun lower middle income countries, menunjukkan bahwa variabel bebas yang dipakai dalam penelitian ini mampu menjelaskan variabel terikat dengan sangat baik karena nilai $\mathrm{R}^{2}$ yang melebihi 90 persen. Secara umum dapat dikatakan bahwa hasil pengujian $\mathrm{R}^{2}$ dalam penelitian ini mendekati nilai 100 persen, yang berarti variabel bebas mutlak menjelaskan variabel terikat secara sempurna. Besarnya nilai $\mathrm{R}^{2}$ dalam penelitian ini dapat dipengaruhi oleh pemilihan metode FEM, yang memungkinkan nilai koefisien determinasi menjadi lebih besar. Perlu diketahui, kelemahan mendasar metode FEM pada koefisien determinasi yaitu bias terhadap jumlah variabel independen yang masuk ke dalam model.

Berdasarkan besaran pengaruh tiap variabel bebas yang menunjukkan pengaruh signifikan terhadap variabel terikat, dapat dibuktikan tentang hipotesis EKC di negara-negara berpendapatan tinggi dan negara-negara berpendapatan menengah rendah di Asia, dan menjelaskan perbedaan pengaruh variabel bebas terhadap variabel terikat antara sebelum dan setelah berlakunya program MDGs.

Tabel 2. Hasil Pengujian Hipotesis EKC di Asia

\begin{tabular}{lllll}
\hline \multirow{2}{*}{ Sampel } & \multicolumn{2}{c}{ Nilai Koefisien } & \multirow{2}{*}{ Turning Point } & Terjadinya EKC \\
\cline { 2 - 3 } & GDP & GDP $^{2}$ & & Akan terjadi ke depan \\
\hline High Income Countries & 3.498 & -0.034 & USD 51.44 rb & Tidak terjadi \\
\hline $\begin{array}{l}\text { Lower Middle Income } \\
\text { Countries }\end{array}$ & -68.74 & 6.599 & USD 5.208 rb & \\
\hline
\end{tabular}

Sumber: Data diolah

\section{Hipotesis Environmental Kuznets Curve (EKC) di Asia}

Hipotesis Environmental Kuznets Curve (EKC) ini dikemukakan oleh Grossman \& Krueger pada tahun 1995. Dalam hipotesis tersebut dijelaskan hubungan pertumbuhan ekonomi dengan kerusakan lingkungan yang membentuk model kurva U terbalik. Model kurva terbentuk akibat pertumbuhan ekonomi pada awalnya meningkatkan kerusakan lingkungan, namun dalam jangka panjang, pertumbuhan ekonomi itu sendirilah yang mampu menurunkan kerusakan lingkungan (Grossman \& Krueger, 1995). Hipotesis ini dikenal sebagai EKC karena kemiripannya dengan Kurva Kuznets U terbalik yang menjelaskan hubungan antara ketimpangan pendapatan dan pertumbuhan ekonomi.

Tabel 2 yang merupakan ringkasan hasil uji, yang menunjukkan adanya perbedaan hasil pengujian hipotesis EKC di Asia, baik di negaranegara high income ataupun di negara-negara lower middle income. Hipotesis EKC dinyatakan berlaku apabila variabel GDP per kapita memiliki nilai koefisien positif dan variabel $\mathrm{GDP}^{2}$ per kapita kuadrat memiliki nilai koefisien negatif.

Berdasarkan perhitungan statistik, di negaranegara high income Asia (Singapura, Jepang, Korea Selatan, Hongkong, Brunei Darussalam, Bahrain, Israel, Saudi Arabia, United Emirates Arab, dan Oman), hipotesis EKC saat ini belum terjadi, namun dalam jangka panjang hipotesis EKC dapat terjadi. Dengan asumsi ceteris paribus, nilai pada Tabel 2 secara umum menunjukkan bahwa setiap kenaikan GDP per kapita sebesar USD 1,000 pada negara high income akan meningkatkan emisi $\mathrm{CO}_{2}$ sebesar 3.498 metrik ton per kapita. Peningkatan ini terus menerus berlangsung sampai pada negara-negara tersebut

18 I Jurnal Ekonomi dan Pembangunan Vol 27, No. 2, 2019 
mencapai tingkat GDP per kapita sebesar USD 51.44 ribu. Setelah nilai GDP per kapita tersebut dilalui, maka emisi $\mathrm{CO}_{2}$ mulai menurun sebesar 0.034 metrik ton per kapita pada setiap kenaikan USD 1,000 GDP per kapita. Karena saat ini hanya negara Uni Emirate Arab yang pernah mencapai GDP per kapita lebih dari USD 51.44 ribu (dan Singapura di tahun 2014), sementara negara lain masih di bawahnya, maka hipotesis EKC belum terjadi di negara-negara high income, namun kedepan hipotesis EKC dapat tercapai karena nilai GDP positif sedangkan nilai $\mathrm{GDP}^{2}$ negatif. Berdasarkan realitas data seperti tergambar pada Gambar 1, Jepang merupakan negara dengan emisi $\mathrm{CO}^{2}$ teringgi, disusul Korea Selatan dan Saudi Arabia, di mana sepanjang periode penelitian beberapa kali terjadi kondisi di mana emisi $\mathrm{CO}^{2}$ menurun ketika GDP per kapita meningkat, sehingga ke depan hipotesis EKC dapat berlaku di sini.

Menggunakan perspektif pembangunan ekonomi, akan berlakunya hipotesis EKC pada negara-negara high income dalam penelitian ini sejalan dengan konsep pembangunan berkelanjutan yang menginginkan bahwa pembangunan yang dilakukan saat ini harus turut memperhatikan kepentingan generasi mendatang, salah satunya dengan upaya menjaga kualitas lingkungan. (Grossman \& Krueger 1995). Selain itu, beberapa penelitian lain yang telah dilakukan juga memiliki hasil yang serupa. Sejalan dengan hasil penelitian, Pao dan Tsai (2010) dengan judul $\mathrm{CO}_{2}$ Emissions, Energy Consumption and Economic Growth, juga membuktikan berlakunya pola $\mathrm{U}$ terbalik dalam menjelaskan hubungan pertumbuhan ekonomi dan emisi $\mathrm{CO}_{2}$ di kawasan BRIC kecuali Rusia. Selain itu, Murniati (2018) juga memiliki hasil penelitian serupa yang membenarkan berlakunya hipotesis EKC baik di Asia Timur maupun di Asia Tenggara.

Terlepas dari hasil penelitian yang membenarkan akan berlakunya hipotesis EKC, kemampuan menurunkan emisi $\mathrm{CO}_{2}$ ditentukan oleh negara itu sendiri, meskipun hasil penelitian EKC meramalkan negara tersebut akan mampu menurunkan emisi $\mathrm{CO}_{2}$ pada pencapaian GDP per kapita sebesar USD 51,440, namun bila tidak diimbangi dengan upaya serius, maka penurunan emisi $\mathrm{CO}_{2}$ tidak akan terwujud.

Hal sebaliknya terjadi di negara-negara lower middle income Asia (Vietnam, Philipina, Myanmar, Indonesia, India, Sri Lanka, Banglades, Tunisia, Mongolia, dan Morocco), di mana hipotesis EKC tidak terbukti baik saat ini maupun ke depan. Bedasarkan Tabel 2, variabel GDP per kapita bertanda negatif, dan variabel $\mathrm{GDP}^{2}$ per kapita bertanda positif, sehingga membentuk model kurva U, bukan $U$ terbalik. Tabel 2 menunjukkan bahwa setiap kenaikan GDP per kapita sebesar USD 1,000 pada negara lower middle income mampu menurunkan emisi $\mathrm{CO}_{2}$ sebesar 68.745 metrik ton per kapita. Penurunan ini terus menerus berlangsung sampai pada negara tersebut mencapai tingkat GDP per kapita sebesar USD 5.208. Setelah nilai GDP per kapita tersebut dilalui, emisi $\mathrm{CO}_{2}$ akan cenderung meningkat sebesar 6.599 metrik ton per kapita pada setiap kenaikan GDP per kapita USD 1,000.

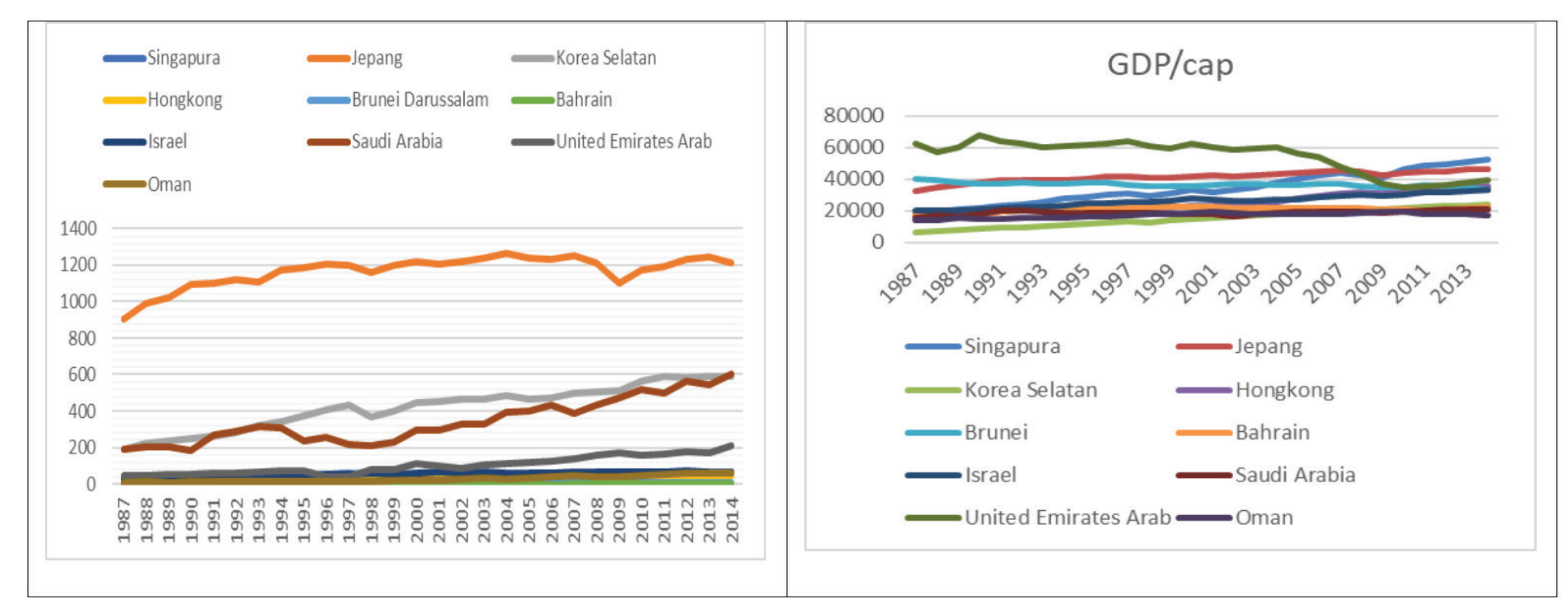

Gambar 2. Emisi $\mathrm{CO}_{2}$ dan GDP per capita di high income Asia 
Ada beberapa kemungkinan mengapa hipotesis EKC belum akan terjadi di negaranegara lower middle income. Pertama, negaranegara lower middle income masih berada dalam awal-awal pembangunan ekonomi dibandingkan dengan negara-negara high income, kedua awal pembangunan ekonomi di masing-masing negara tidak sama, misalnya Vietnam, Myanmar dan Banglades yang lebih belakangan melakukan pembangunan dibandingkan dengan Indonesia dan India yang sudah lebih dahulu melakukan pembangunan ekonominya. Ketiga, adanya ketidaksamaan atas besarnya emisi $\mathrm{CO}_{2}$ setiap negara dalam kelompok lower middle income. Namun secara individu, ada negara-negara ketika GDP per kapita naik bersamaan dengan emisi $\mathrm{CO}_{2}$ yang menurun, misalnya terjadi di Indonesia pada periode 2010-2012 (lihat Gambar 3). Hasil yang bervariasi dalam studi empiris hipotesis EKC ini dapat terjadi karena perbedaan pendekatan dalam objek studi dan periode penelitian (Beck \& Joshi, 2015).

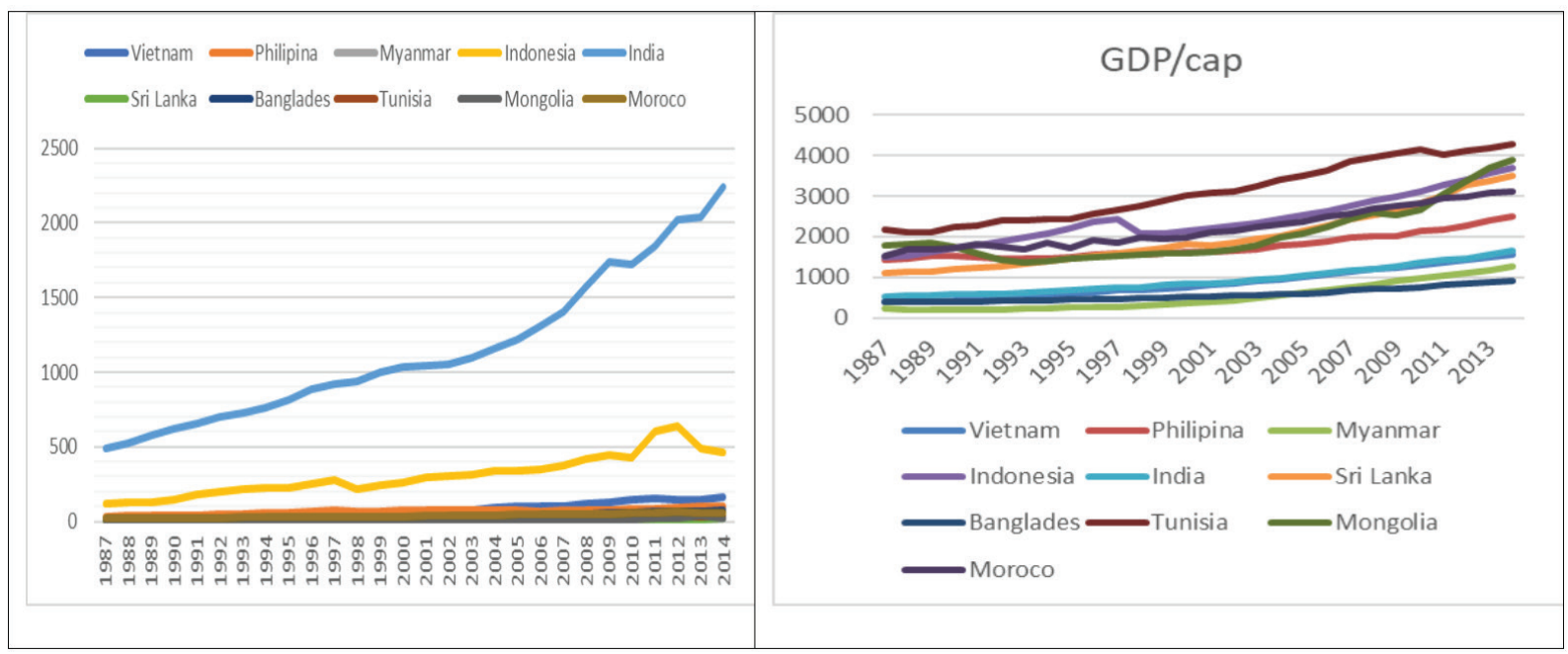

Gambar 3. Emisi $\mathrm{CO}_{2}$ dan GDP/cap di lower middle income Asia

Kurva U juga ditemukan oleh penelitian sebelumnya (Abdurahman, 2012), untuk melihat pengaruh pertumbuhan dan keterbukaan ekonomi terhadap emisi $\mathrm{CO}_{2}$ dalam jangka panjang. Hasil yang sama juga pernah dikaji berkaitan dengan hubungan antara pembangunan ekonomi dan defortasi hutan tropis, yang membentuk model kurva U saat memperlihatkan hubungan kedua variabel. Hasil temuan yang membentuk model kurva $U$ dapat diinterpretasikan sebagai sebuah model yang melihat bagaimana pengorbanan lingkungan dalam rangka mencapai output perekonomian (Kuswantoro, 2009). Dalam arti kata lain, untuk mendapatkan GDP per kapita yang lebih tinggi, maka semakin tinggi pula emisi $\mathrm{CO}_{2}$ yang dikeluarkan. Terjadinya peningkatan emisi $\mathrm{CO}_{2}$ setelah negara memiliki GDP per kapita yang lebih besar dimungkinkan terjadi karena adanya penemuan teknologi produksi yang lebih canggih untuk keperluan perluasan industri.

Anomali terjadi pada negara lower middle income yang memperlihatkan bahwa semakin kaya suatu negara, negara tersebut semakin menguras sumber daya alamnya untuk memperoleh output perekonomian yang lebih besar, yang secara sadar atau tidak sadar telah mengorbankan kualitas lingkungan. Dengan demikian, hasil estimasi menggambarkan bahwa emisi $\mathrm{CO}_{2}$ akan terus meningkat seiring dengan pertumbuhan GDP per kapita dalam jangka panjang.

Sejalan dengan hal itu, Halkos (2009) dalam penelitiannya menjelaskan alasan terjadinya penurunan kualitas lingkungan. Menurut Halkos, perkembangan alami dari pembangunan ekonomi berasal dari sektor pertanian yang bersih dari polusi menuju sektor industri yang sarat akan polusi, serta berakhir pada sektor jasa dan pelayanan yang akan membersihkan dan mengembalikan kualitas lingkungan. Secara khusus, pembangunan ekonomi yang dikaitkan dengan pencemaran lingkungan memiliki tiga efek berbeda yang dapat menjelaskan pengaruh pertumbuhan ekonomi terhadap degradasi lingkungan yakni efek skala, efek komposisi, dan efek teknis. Peningkatan 
emisi sebagai dampak dari pertumbuhan ekonomi pada jangka panjang merupakan dampak dari efek skala yang terjadi. Sehingga bertambahnya volume kegiatan ekonomi akan meningkatkan jumlah emisi $\mathrm{CO}_{2}$ yang dilepaskan ke udara (Abdurahman, 2012). Oleh sebab itu, penemuan kurva $\mathrm{U}$ yang terjadi pada negara lower middle income wajar adanya. Pada dasarnya negara lower middle income berada dalam fase pembangunan yang seringkali menyampingkan lingkungan. Bila dikaitkan dengan hasil penelitian pada negara high income, pendapatan per kapita negara lower middle income yang menjadi tolok ukur titik balik kurva masih jauh tertinggal dari angka 51 ribu USD. Dengan pendapatan sebesar itu barulah negara high income mampu secara perlahan menurunkan tingkat emisi $\mathrm{CO}_{2}$, diharapkan dengan adanya kemajuan teknologi yang semakin cepat, mampu pula mempercepat negara lower middle income untuk berhasil menurunkan tingkat emisi $\mathrm{CO}_{2}$.

\section{Perubahan Pengaruh Pertumbuhan Ekonomi, Konsumsi Energi, dan Populasi Penduduk terhadap Emisi $\mathrm{CO}_{2}$ Sebelum dan Setelah MDGs}

Program MDGs diwujudkan sebagai upaya nyata melindungi kelestarian lingkungan, yang secara resmi berlaku untuk seluruh anggota PBB selama tahun 2000 sampai tahun 2015. Dalam menjalankan program MDGs, tiap negara memiliki caranya tersendiri. Salah satu caranya yaitu dengan mengendalikan faktor-faktor yang mempengaruhi emisi $\mathrm{CO}_{2}$, sehingga tidak memperparah kerusakan lingkungan. Untuk melihat perbedaan pengaruh variabel bebas terhadap variabel terikat sebelum dan setelah berlakunya MDGs, ditambahkan variabel dummy pada setiap variabel bebas. Berikut ini adalah Tabel 3 yang merupakan ringkasan hasil penelitian tersebut.

Berdasarkan Tabel 3 diketahui bahwa setiap variabel bebas memiliki pengaruh yang berbeda beda terhadap emisi $\mathrm{CO}_{2}$. Di negara-negara high income Asia, semua variable bebas (GDP per kapita, konsumsi energi, dan populasi penduduk) selama tahun 1987-2014 mempunyai pengaruh positif terhadap emisi $\mathrm{CO}_{2}$. Hal tersebut berarti bahwa jika terjadi peningkatan GDP per kapita, konsumsi energi, dan populasi penduduk dalam suatu negara maka emisi $\mathrm{CO}_{2}$ yang dihasilkan negara tersebut meningkat.

Namun bila dilihat secara khusus, yaitu dengan membandingkan periode sebelum dan setelah MDGs (dengan menambahkan variabel dummy), ada perbedaan pengaruh variable bebas pada emisi $\mathrm{CO}_{2}$. Setelah berlakunya MDGs, meningkatnya GDP per kapita sebesar USD 1,000 mampu menurunkan emisi $\mathrm{CO}_{2}$ sebesar 1,090 metrik ton per kapita. Keberhasilan negara high income (khususnya Jepang) dalam menurunkan pengaruh terhadap emisi $\mathrm{CO}_{2}$ sejalan dengan urgensi penanganan masalah perubahan iklim. Kesepakatan antar negara, khususnya negara high income atau negara maju dunia, termasuk juga yang ada di Asia, untuk menekan emisi $\mathrm{CO}_{2}$, dipelopori dengan adanya perjanjian Protokol Kyoto pada Desember, 1997. Jepang sebagai tuan rumah, dan negara maju lainnya yang meratifikasi protokol ini, berkomitmen untuk mengurangi emisi atau pengeluaran $\mathrm{CO}_{2}$ dan lima gas rumah kaca lainnya, agar memperlambat pemanasan global.

Tabel 3. Pengaruh Variabel Bebas Terhadap Emisi $\mathrm{CO}_{2}$ Sebelum dan Setelah MDGs

\begin{tabular}{lllll}
\hline & \multicolumn{2}{c}{ Koefisien variabel bebas } & \multicolumn{2}{c}{$\begin{array}{c}\text { Koefisien variabel bebas (dengan } \\
\text { dummy) }\end{array}$} \\
\hline \multirow{2}{*}{ High Income } & GDP & 3.49 & D00*GDP & -1.09 \\
\cline { 2 - 5 } & KE & 5.00 & D00*KE & 2.24 \\
\cline { 2 - 5 } & POP & 24.43 & D00*POP & 0.54 \\
\hline \multirow{2}{*}{ Lower Middle Income } & GDP & -68.74 & D00*GDP & 17.79 \\
\cline { 2 - 5 } & KE & 118.6 & D00*KE & 20.70 \\
\cline { 2 - 5 } & POP & 3.535 & D00*POP & -0.08 \\
\hline
\end{tabular}

Sumber: Data diolah, signifikan pada taraf 5\% 
Setelah berjalan kesepakatan Protokol Kyoto, pada tahun 2000 disepakati pula oleh seluruh anggota PBB mengenai program MDGs (Milennium Development Goals) yang salah satu poin capaiannya adalah mencapai keseimbangan antara kesehatan ekonomi dan lingkungan. Sasaran utama dua program tersebut adalah negara maju, tak terkecuali yang ada di Asia, untuk itu, negara tersebut terdorong untuk menjalankan berbagai program yang mendukung kelestarian lingkungan. Sejalan dengan itu, Jepang yang menjadi salah satu sasaran utama, menjalankan upaya untuk mengurangi pengeluaran emisi $\mathrm{CO}_{2}$ dengan cara mendorong penggunaan energi terbarukan, dan juga energi nuklir. Banyak negara maju lainnya juga telah menetapkan regulasi yang berkaitan dengan batubara, pengunaan energi terbarukan, dan kendaraan beremisi rendah. Melalui berbagai upaya tersebut, pada tahun 2014 analisis tahunan PWC menemukan penurunan intensitas karbon tertajam sejak tahun 2000. Analisis tersebut sejalan dengan temuan dalam penelitian ini, yaitu adanya keberhasilan negara maju (khususnya Jepang) menurunkan pengaruh pendapatan per kapita terhadap emisi $\mathrm{CO}_{2}$. Di negara-negara high income Asia yang diteliti, konsumsi energi dan populasi penduduk juga memiliki nilai koefisien positif terhadap emisi $\mathrm{CO}_{2}$ setelah ditambahkan variabel dummy. Hal tersebut berarti bahwa setelah berlakunya program MDGs, konsumsi energi dan populasi penduduk mempunyai pengaruh semakin besar terhadap emisi $\mathrm{CO}_{2}$. Pengaruh positif konsumsi energi terhadap emisi $\mathrm{CO}_{2}$ dapat terjadi karena pasca berlakunya MDGs industri pada negara high income Asia, berproduksi terus-menerus dengan skala yang sangat besar, terlepas dari upayanya untuk menekan laju emisi $\mathrm{CO}_{2}$. Demikian pula industri tambang seperti batu bara, minyak bumi, dan gas alam, yang masih menjadi andalan bagi perekonomian, turut meningkatkan emisi CO2. Kita tahu bahwa kegiatan produksi di tambang dilakukan dengan cara membakar bahan bakar fosil untuk menghasilkan energi, maka karbon dalam bahan bakar bereaksi dengan oksigen, untuk membentuk gas karbon dioksida $\left(\mathrm{CO}_{2}\right)$. Dengan kata lain, meningkatnya konsumsi energi tersebut mendorong meningkatnya emisi $\mathrm{CO}_{2}$.
Sama halnya dengan konsumsi energi, setelah berlakunya MDGs, pengaruh populasi penduduk terhadap emisi $\mathrm{CO}_{2}$ pada negara high income semakin besar. Menurut Goodness dan Prosper (Goodness \&Prosper, 2017), banyaknya jumlah penduduk mampu meningkatkan permintaan energi, yang berbahan bakar fosil. Bila terus menerus berlanjut, maka peningkatan emisi $\mathrm{CO}_{2}$ tidak dapat dihindari. Terlebih untuk kasus negara maju, yang pada dasarnya kemajuan teknologi sudah melebihi negara lainnya. Penduduk di negara maju, pasti sangat bergantung pada teknologi, yang membutuhkan listrik, kemudian kendasaraan pribadi, yang membutuhkan bahan bakar, sebagai tenaganya. Selain pola hidup masyarakatnya yang tidak ramah lingkungan, semakin banyaknya jumlah masyarakat juga berimplikasi pada meningkatnya kuantitas transportasi, penurunan ruang terbuka hijau, perubahan gaya hidup yang mendorong pertumbuhan konsumsi energi, ketergantungan kepada minyak bumi sebagai sumber energi. Sejalan dengan hal tersebut, Harris seorang ilmuan ekonomi menyatakan bahwa pertumbuhan penduduk dan peningkatan standar hidup akan sangat membutuhkan jumlah konsumsi energi yang semakin tinggi (Harris, 2002). Oleh karena itu, tidak heran jika populasi penduduk di negara maju dapat meningkatkan jumlah emisi $\mathrm{CO}_{2}$.

Berbeda dengan temuan di negara maju, di negara-negara lower middle income selama tahun 1987-2014 menunjukkan pengaruh GDP per kapita terhadap emisi $\mathrm{CO}_{2}$ masih negatif. Pengaruh negatif tersebut bukan berarti bahwa negara-negara lower middle income lebih dapat menjaga kelestarian lingkungan daripada negara high income, namun lebih kepada waktu pelaksanaan pembangunan yang masih baru berjalan dibanding di negara maju. Di negaranegara lower middle income Asia yang diteliti, pembangunan ekonomi dilakukan sekitar tahun 70-an, bahkan ada yang di tahun 90-an, berbeda dengan pembangunan ekonomi di negara-negara maju yang lebih dahulu dilakukan. Selain itu kegiatan industri di negara-negara lower middle income Asia tidak seaktif di negara-negara high income. Baru setelah tahun 2000 (berlakunya MDGs), kegiatan pembangunan ekonomi di negara-negara ini menyebabkan meningkatnya 
emisi $\mathrm{CO}_{2}$. Pasca tahun 2000, perkembangan aktifitas industri semakin pesat, selain itu negara berkembang seperti Indonesia juga aktif dalam kegiatan pertambangan. Sementara itu ada perubahan konsumsi energi yang tinggi setelah berlakunya MDGs, karena negara-negara ini berada pada tahap pembangunan ekonomi, dimana dalam prosesnya membutuhkan energi yang lebih banyak, dan pendapatan nasional yang dimilikinya belum cukup untuk melakukan tindakan preventif ataupun menanggulangi degradasi lingkungan. Adapun pengaruh populasi penduduk pasca berlakunya MDGs, memiliki koefisien negatif dan signifikan terhadap emisi $\mathrm{CO}_{2}$. Hal ini bukan berarti bahwa setiap penambahan populasi penduduk mampu menurunkan emisi $\mathrm{CO}_{2}$, namun lebih kepada proporsi peningkatan jumlah penduduk yang lebih tinggi dibandingkan proporsi peningkatan emisi $\mathrm{CO}_{2}$ yang masih rendah karena pembangunan belum sepesat di negara-negara maju.

\section{KESIMPULAN}

Hipotesis EKC dinyatakan terbukti apabila dalam hasil penelitian menunjukkan koefisien GDP per kapita bertanda positif dan koefisien GDP per kapita kuadrat bertanda negatif, dengan titik balik (turning point) tertentu, sehingga kurva berbentuk U terbalik. Hasil penelitian menunjukkan bahwa di negara-negara high income Asia hipotesis EKC akan terjadi ketika GDP per capita mereka mencapai USD 51.44 ribu, yang sepanjang periode penelitian hanya Singapore yang sudah mencapainya. Di Negara-negara high income ini, Jepang, Korea Selatan dan Arab Saudi merupakan negara yang beberapa kali berhasil menurunkan emisi CO2 ketika GDP per kapita naik. Berlakunya hipotesis EKC ini diartikan bahwa di masa depan, setelah melampaui turning point, negara-negara high income akan mampu menurunkan emisi $\mathrm{CO}_{2}$. Sedangkan di negara-negara low middle income Asia, koefisien GDP per kapita bertanda negatif, dan koefisien $\mathrm{GDP}^{2}$ per kapita bertanda positif, sehingga kurva membentuk huruf $U$, atau dengan kata lain hipotesis EKC tidak berlaku. Namun di
Indonesia pernah berhasil menurunkan emisi $\mathrm{CO} 2$ ketika GDP per kapita naik, yaitu pada periode 2010-2012.

Di negara-negara high income sebelum MDGs ditetapkan, semakin tinggi tingkat GDP per kapita, konsumsi energi (KE) dan jumlah penduduk (Pop) telah meningkatkan emisi $\mathrm{CO}_{2}$. Namun pasca penetapan MDGs, semakin tinggi GDP per kapita, negara semakin mampu menurunkan emisi $\mathrm{CO}_{2}$, namun KE dan Pop tetap berkontribusi atas meningkatnya emisi $\mathrm{CO}_{2}$. Sedangkan di negara-negara lower middle income (khususnya India dan Indonesia), emisi $\mathrm{CO}_{2}$ sudah naik di awal-awal periode penelitian ketika GDP masih rendah, itulah sebabnya hubungan antara GDP per kapita dan emisi CO2 berbanding terbalik. Namun setelah tahun 2000 (penetapan MDGs), meningkatnya GDP per kapita, KE dan Pop menyebabkan meningkatkan emisi $\mathrm{CO}_{2}$ di semua negara.

Untuk mengurangi masalah kerusakan lingkungan akibat meningkatnya emisi $\mathrm{CO}_{2}$, khususnya di negara-negara berpenghasilan menengah rendah seperti Indonesia, beberapa alternatif dapat dilakukan. Yang paling efektif adalah pengenaan sanksi pada badan usaha atau perorangan yang dengan sengaja menyebabkan meningkatnya emisi $\mathrm{CO}_{2}$ ini, melalui UU yang dibuat DPR. Selain itu literasi bahaya akibat pencemaran lingkungan perlu digalakkan melalui berbagai saluran, sehingga dapat mengurangi/ menurunkan emisi CO2. Berkaitan dengan temuan penelitian, konsumsi energi fosil sebaiknya dikurangi, digantikan dengan energi yang ramah lingkungan seperti energi listrik dan energi surya. Untuk itu pemakaian energi fosil diberbagai keperluan saat ini sudah saatnya dikurangi, dan digantikan dengan menggunakan energi ramah lingkungan.

Terlepas dar temuan, penelitian ini memiliki beberapa kekurangan seperti hanya memberikan kesimpulan secara umum di tiap kelompok negara high income dan lower middle income di Asia, sehingga penelitian dengan pendekatan individu negara perlu dilakukan. 


\section{REFERENSI}

Abdurahman, D. A. (2012). Dampak pertumbuhan dan keterbukaan ekonomi terhadap degradasi lingkungan. Departemen Ilmu Ekonomi Fakultas Ekonomi Dan Manajemen Institut Pertanian Bogor, 1-142.

Ali, A., Khatoon, S., Ather, M., \& Akhtar, N. (2015). Modeling Energy Consumption , Carbon Emission and Economic Growth : Empirical Analysis for Pakistan. International Journal of Energy Economics and Policy, 5(2), 624-630.

Basarir, A., \& Arman, H. (2013). Sustainable development and environmental Kuznets curve in GCC countries. In Proceedings of the 13th International Conference on Environmental Science and Technology, Athens, Greece, September 5 (Vol. 7).

Beck, K. A., \& Joshi, P. (2015). An Analysis of the Environmental Kuznets Curve for Carbon Dioxide Emissions: Evidence for OECD and Non-OECD Countries. European Journal of Sustainable Development, 4(3), 33-45. https://doi.org/10.14207/ejsd.2015.v4n3p33

Beckerman, W. (1992). Economic growth and the environment: Whose growth? whose environment? World Development, 20(4), 481-496. https://doi.org/10.1016/0305750X(92)90038-W

Camci-Cetin, Sema, Murat Mustafa Kutluturk, and Ahmet Kibar Cetin. 2018. "The Impact of Income Levels of Countries on Environmental Pollution: Testing the Environmental Kuznets Curve " Fresenius Environmental Bulletin 27 (9):5804-5810.

Dasgupta, S., Laplante, B., Wang, H., \& Wheeler, D. (2002). Confronting the Environmental Kuznets Curve. Journal of Economic Perspectives, 16(1), 147-168. https://doi. org/10.1257/0895330027157

Endeg, T. W. (2015). Economic growth and environmental degradation in Ethiopia: An environmental Kuznets curve analysis approach. Journal of Economics and International Finance, 7(4), 72-79. https:// doi.org/10.5897/JEIF2015.0660

Galeotti, M. (2007). Economic growth and the quality of the environment: Taking stock. Environment, Development and Sustainability, 9(4), 427-454. https://doi. org/10.1007/s10668-006-9030-y

Goetzke, Frank, and Tilmann Rave. 2015. "Regional air quality and happiness in Germany." International Regional Science Review 38 (4):437-451.

Grossman, G. M., \& Krueger, A. B. (1995). Economic Growth and the Environment. The Quarterly Journal of Economics, 110(2), 353-377. https://doi.org/10.2307/2118443

Gujarati, D. (2010). Dasar-Dasar Ekonometrika. Jakarta: Salemba Empat.

Halkos, G. (2009). Environment and Sustainable Development. International Journal of Global Environmental Issues, (17), 111-116.

Harris, J. M. (2002). Environmental and Natural Resource Economics: A Contemporary Approach. Boston: Houghton Mifflin Co.

Inglesi-Lotz, R., \& Bohlmann, J. (2014). Environmental Kuznets curve in South Africa: To confirm or not to confirm? (No. 6378). EcoMod.

Kementerian Negara Lingkungan Hidup. (2009). Bahan Ajar Pelatihan Penilaian AMDAL.

Kuswantoro, D. P. (2009). Pembangunan Ekonomi dan Deforestasi Hutan Tropis.

Landrigan, Philip J. 2017. "Air pollution and health." The Lancet Public Health 2 (1):e4-e5.

Lean, H. H., \& Smyth, R. (2010). CO2 emissions, electricity consumption and output in ASEAN. Applied Energy, 87(6), 1858-1864.

Maryam, J., Mittal, A., \& Sharma, V. (2017). $\mathrm{CO} 2$ Emissions, Energy Consumption and Economic Growth in BRICS:An Empirical Analysis. IOSR Journal of Humanities and Social Science, 22(2), 53-58. https://doi. org/10.9790/0837-2202055358

Mrabet, A., Achairi, R., \& Ellouze, A. (2014). The Two-Way relationship between Economic Growth and CO2 Emissions. 2(6), 32-35.

OECD. (2015). Survey Ekonomi OECD Indonesia.

Panayotou, T. (1993). Empirical Test and Policy Analysis of Environmental Degradation at Different Stages of Economic Development. In WORLD EMPLOYMENT PROGRAMME 
RESEARCH. https://doi.org/http://scihub.tw/http://www.ilo.org/public/ libdoc/ ilo/1993/93B09_31_engl.pdf

Pao, H. T., \& Tsai, C. M. (2011). Modeling and forecasting the $\mathrm{CO} 2$ emissions, energy consumption, and economic growth in Brazil. Energy, 36(5), 2450-2458. https:// doi.org/10.1016/j.energy.2011.01.032

Phimphanthavong, H. (2013). The Impacts of Economic Growth on Environmental Conditions in Laos. 4(5), 766-774.

Pratama, M. I. A. (2016). Hipotesis Environmental Kuznets Curve di Indonesia Tahun 19602013. Universitas Diponogoro.

Shaharir, b. M. Z., \& Alinor, M. b. A. K. (2013). The Need for a New Definition of Sustainability. Journal of Indonesian Economy and Business, 28(2), 251-268. https://doi.org/10.1007/978-94-007-2285-9

Suparmoko, M. (2000). Ekonomi Sumber Daya Alam dan Lingkungan. Yogyakarta: BPFE.

Susanti, E. D. (2018). Environmental Kuznet Curve: Hubungan Pertumbuhan Ekonomi dengan Degradasi Kualitas Udara Dalam Pencapaian MilleniumDevelopment Goals (MDGs) di Indonesia. Universitas Negeri Yogyakarta.
UNFCC. (2007). Sekilas Tentang Perubahan Iklim. Retrieved from http://unfccc.int/files/ meetings/cop_13/press/application/pdf/ sekilas_tentang_perubahan_iklim.pdf.

United Nation. (2007). Perkembangan Pencapaian MDGs Indonesia. Jakarta.

WEF. (2017). Global Shapers Survey. Global Shapers Community. Retrieved from http:// www.shaperssurvey2017.org/static/data/ WEF_GSC_Annual_Survey_2017.pdf

WMO. (2017). WMO Statement on The State of The Global Climate in 2017. Retrieved from https://library.wmo.int/doc_num. php?explnum_id $=4453$

World Resource Institute. (2016). Rising To The Challenge.

Zhang, Xin, Xiaobo Zhang, and Xi Chen. 2017. "Happiness in the air: how does a dirty sky affect mental health and subjective well-being?" Journal of environmental economics and management 85:81-94.

Zhu, Q., \& Peng, X. (2012). The impacts of population change on carbon emissions in China during 1978-2008. Environmental Impact Assessment Review, 36, 1-8. 